\title{
"BUKAN MERUPAKAN KERUGIAN NEGARA": ANALISIS IMPLEMENTASI KEBIJAKAN KEUANGAN NEGARA DAN STABILITAS SISTEM KEUANGAN UNTUK PENANGANAN PANDEMI COVID-19
}

\author{
Dian Eka Prastiwi, Fakultas Hukum Universitas Pamulang, \\ Email: dianekaunpam@yahoo.com
}

doi: https://doi.org/10.24843/KS.2020.v08.i09.p11

\begin{abstract}
Abstrak
Penelitian ini bertujuan untuk mengkaji isu krusial yang terkait dengan dikeluarkan PERPU NO. 1 Tahun 2020 tentang Kebijakan Keuangan Negara Dan Stabilitas Sistem Keuangan Untuk Penanganan Pandemi Corona Disease 2019 (“Covid-19”) yang diubah menjadi Undang-Undang Nomor 2 Tahun 2020. Untuk dapat mengetahui makna Kerugian Negara dan Penerapan Itikad baik sesuai dengan Pasal 27. Penelitian ini menggunakan metode normatif dengan menggunakan studi dokumen yang meliputi bahan hukum primer, sekunder dan tersier. Hasil penelitian ini menunjukkan bahwa Undang-Undang Nomor 2 Tahun 2020. Terkait dengan halhal yang terdapat dalam Pasal 27 PERPU No 1 Tahun 2020 juga dinilai berpotensi memunculkan korupsi dengan adanya Pasal 27 ayat 1 terutama frasa "bukan merupakan kerugian Negara". Unsur terpenting dari suatu kerugian Negara adalah adanya perbuatan melawan hukum dan nilai kerugian yang riill. Oleh karena itu, pengaturan frasa "bukan merupakan kerugian Negara" dalam Pasal 27 ayat 1 PERPU No 1 Tahun 2020 agar tidak terjadi salah penafsiran atas Pasal tersebut maka perlu diatur lebih detail dalam penjelasan pasal demi pasal pada PERPU yang dimaksud.
\end{abstract}

Kata Kunci: Perpu, Kerugian Negara, Stabilitas Keuangan Negara

\section{Abstract}

This study aims to examine the crucial issues associated with the issuance of PERPU NO. 1 of 2020 concerning State Financial Policy and Financial System Stability for Handling the 2019 Corona Disease Pandemic ("Covid-19") which was amended to Law Number 2 of 2020. To be able to find out the meaning of State Loss and Implementation of Good faith in accordance with Article 27. This study uses a normative method by using document studies which include primary, secondary and tertiary legal materials. The results of this study indicate that Law Nomoor 2 of 2020. In relation to matters contained in Article 27 of PERPU No. 1 of 2020 it is also considered to have the potential to cause corruption with the existence of Article 27 paragraph 1, especially the phrase "not a loss to the State". The most important element of a State loss is an act against the law and the real value of the loss. Therefore, the regulation of the phrase "not a loss to the State" in Article 27 paragraph 1 of PERPU No. 1 of 2020 so that there is no misinterpretation of the Article, it is necessary to regulate in more detail the explanation of article by article in the PERPU referred to.

Keywords: Perpu, State Loss, State Financial Stability 


\section{A. Pendahuluan}

\subsection{Latar Belakang Masalah}

Pemerintah baru saja mengeluarkan UU Nomor 2 Tahun 2020 Tentang Penetapan Peraturan Pemerintah Pengganti UU Nomor 1 Tahun 2020 ("PERPU 1/2020") mengenai Kebijakan Keuangan Negara Dan Stabilitas Sistem Keuangan Untuk Penanganan Pandemi Corona Disease 2019 (“Covid-19"). Peraturan itu dibuat dalam rangka menghadapi ancaman yang membahayakan perekonomian nasional secara nyata dan mempunyai efek domino di berbagai sector. Perlu diketahui bahwa latar belakang terbitnya PERPU 1/2020 karena adanya kegentingan yang memaksa sebagai akibat dari adanya pandemi Covid-19. Kegentingan ini akan berdampak pada perekonomian nasional dan stabilitas sistem keuangan.

Potensi langsung terhadap perekonomian bangsa dapat dipahami bahkan perlu dilakukannya relaksasi dan realokasi APBN. Relaksasi, realokasi APBN guna memulihkan perekonomian dan membentuk jaring pengaman sosial (social safety net). PERPU 1/2020 juga memberikan legitimasi kewenangan terhadap beberapa instansi pemerintahan terkait. Untuk diketahui masyarakat semuanya, PERPU 1/2020 dinilai memiliki pasal yang mempunyai tafsiran secara tidak langsung menaungi instansi pemerintahan atau para pengambil pejabat yang membuat kebijakan tertentu dalam melaksanakan kewenangannya terkait masalah penanganan Covid-19 Pasal yang diduga bermasalah tersebut adalah Pasal 27 dalam PERPU 1/2020 yang berbunyi pada ayat (1) menyatakan biaya yang telah dikeluarkan Pemerintah dan/atau lembaga anggota KSSK dalam rangka pelaksanaan kebijakan pendapatan negara termasuk kebijakan di bidang perpajakan, kebijakan belanja negara termasuk kebijakan di bidang keuangan daerah, kebijakan pembiayaan, kebijakan stabilitas sistem keuangan, dan program pemulihan ekonomi nasional, merupakan bagian dari biaya ekonomi untuk penyelamatan perekonomian dari krisis dan bukan merupakan kerugian negara'. Pada ayat (2) berbunyi 'anggota KSSK, Sekretaris KSSK, anggota sekretariat KSSK, dan pejabat atau pegawai Kementerian Keuangan, Bank Indonesia, Otoritas Jasa Keuangan, serta Lembaga Penjamin Simpanan, dan pejabat lainnya, yang berkaitan dengan pelaksanaan Peraturan Pemerintah Pengganti UU ini, tidak dapat dituntut baik secara perdata maupun pidana jika dalam melaksanakan tugas didasarkan pada itikad baik dan sesuai dengan ketentuan peraturan perundang- undangan, dan pada ayat (3) berbunyi 'segala tindakan termasuk keputusan yang diambil berdasarkan Peraturan Pemerintah Pengganti UU ini bukan merupakan objek gugatan yang dapat diajukan kepada peradilan tata usaha negara'.1

Yang dapat dilihat di dalam persoalan ini khususnya yang terdapat di dalam Pasal 27 ayat 1 bahwasannya biaya yang dikeluarkan oleh Pemerintah dan KSSK di dalam pelaksanaan kebijakan Negara termasuk kebijakan di bidang perpajakan, kebijakan belanja negara termasuk kategori kebijakan di bidang keuangan daerah, kebijakan pembiayaan, kebijakan stabilitas sistem keuangan, dan program pemulihan ekonomi nasional, merupakan bagian dari biaya ekonomi untuk penyelamatan perekonomian dari krisis dan bukan merupakan kerugian negara.

Definisi dari kerugian Negara jika dilihat dalam Undang-Undang Nomor 1 Tahun 2004 tentang Pembendaharaan Negara Pasal 1 angka 22 berbunyi “Kerugian

1 Pasal 27 Perppu Nomor 1 Tahun 2020 tentang Kebijakan Keuangan Negara dan Stabilitas Sistem Keuangan untuk Penanganan Pandemi Corona Virus Disease 2019 (Covid-19) dan/atau Dalam Rangka Menghadapi Ancaman yang Membahayakan Perekonomian Nasional dan/atau Stabilitas Sistem Keuangan 
Negara/Daerah adalah kekurangan uang, surat berharga, dan barang, yang nyata dan pasti jumlahnya sebagai akibat perbuatan melawan hukum baik sengaja maupun lalai." Jika dilihat inti yang terkandung di dalam Pasak 1 angka 22 UU No. 1 Tahun 2004 mengandung arti bahwa tidak semua kondisi berkurangnya uang, surat berharga, dan barang milik negara dinyatakan sebagai kerugian negara

Pasal tersebut dianggap berbahaya karena akan "melegitimasi" para aparatur pejabat pemerintahan yang menggunakan uang anggaran negara terkait penanganan Covid-19 tidak bisa digugat secara pidana, perdata, maupun di pengadilan tata usaha negara (PTUN). Selain kewenangan yang dinilai kebal hukum oleh masyarakat luas, Pasal 27 PERPU 1/2020 dinilai juga sangat berpotensi memunculkan korupsi disebabkan oleh adanya Pasal 27 ayat (1) terutama frasa "bukan merupakan kerugian negara". Selain itu pasal tersebut juga dinilai tidak memiliki urgensi dan alasan hukum yang kuat apalagi UU Nomor 17 Tahun 2003 tentang Keuangan Negara telah mengatur keuangan negara dalam kondisi tidak normal atau darurat sebagaimana diatur dalam Pasal 27 ayat (3), ayat (4) dan ayat (5). ${ }^{2}$

Anggaran Negara adalah suatu dokumen yang memuat perkiraan penerimaan dan pengeluaran serta rincian kegiatan-kegiatan di bidang pemerintahan negara yang berasal dari pemerintah untuk jangka waktu satu tahun ke depan. Jumlah penerimaan dan jumlah pengeluaran tersebut sering direncanakan dengan cara berimbang untuk tahun anggaran negara yang bersangkutan. Hal ini bertujuan untuk mengetahui sejauh mana kemampuan pemerintah dalam mengelola anggaran negara sehingga tidak menimbulkan kerugian (defisit) terhadap pengelolaan anggaran negara.

Anggaran negara yang ditetapkan dalam bentuk UU mengandung unsur-unsur antara lain:

1. Dokumen hukum yang memiliki kekuatan hukum mengikat;

2. Rencana penerimaan negara baik dari sector pajak, bukan pajak, dan hibah;

3. Rencana pengeluaran negara baik bersifat rutin maupun pembangunan;

4. Kebijakan negara terhadap kegiatan-kegiatan di bidang pemerintahan yang memperoleh prioritas atau tidak memperoleh prioritas;

5. Masa berlaku hanya satu tahun kecuali diberlakukan untuk tahun anggaran negara ke depan.

Kelima unsur Anggaran negara di atas merupakan satu kesatuan tak terpisahkan sehingga menggambarkan sebuah kemampuan negara dalam jangka waktu satu tahun untuk mewujudkan tujuannya. Unsur-unsur yang terdapat dalam anggaran negara merupakan hal-hal yang bersifat esensial dan tidak dapat dikesampingkan dalam bernegara. Oleh karena itu, anggaran negara tidak dapat dipisahkan dengan suatu tujuan negara yakni memakmurkan rakyat terlepas, mengentaskan kemiskinan dan kemeralatan bagi masyrakatnya. ${ }^{3}$.

Merujuk pada Pasal 22 UUD 1945 (sebelum dan sesudah perubahan) berikut penjelasannya dinyatakan bahwa dalam hal ihwal kegentingan yang memaksa Presiden dapat membentuk Peraturan Pemerintah Penganti UU ("PERPU"), yang merupakan peraturan Perundang-undangan yang mempunyai kedudukan setingkat

${ }^{2}$ https: $/ /$ mkri.id/index.php?page=web.Berita\&id=16330\&menu=2 diakses pada tanggal 29 Mei 2020

${ }^{3}$ Muhammad Djafar Saidi, Hukum Keuangan Negara, PT Rajagrafindo Persada, Jakarta, 2008, hlm. 104 
dengan UU. Berdasarkan alasan tersebut, PERPU adalah sama dengan seperti UU, yaitu:4

1. Menyelenggarakan pengaturan lebih lanjut ketentuan dalam UU Dasar 1945 yang tegas-tegas menyebutnya;

2. Pengaturan lebih lanjut secara umum aturan dasar lainnya dalam Batang Tubuh UUD 1945;

3. Pengaturan lebih lanjut ketentuan dalam ketetapan MPR yang tegas-tegas menyebutnya;

4. Pengaturan di bidang materi konstitusi, seperti:

a. Organisasi, tugas, dan susunan lembaga tinggi negara;

b. Tata hubungan antara negara dan warga negara dan anatara warga negara/penduduk timbal balik.

Bahwa PERPU 1/2020 apakah telah memenuhi ketentuan tiga syarat "kegentingan memaksa" sebagai parameter betapa perlunya seorang Presiden menerbitkan sebuah perppu berdasarkan Putusan MK No. 138/PUU-VII/2009. Tiga syarat tersebut antara lain adalah sebagai berikut:

1. Adanya keadaan mendesak untuk menyelesaikan masalah hukum secara cepat berdasarkan UU;

2. UU yang dibutuhkan belum ada sehingga terjadi kekosongan hukum

3. Kekosongan hukum tersebut tidak dapat diatasi dengan cara membuat UU secara prosedur biasa karena akan memerlukan waktu yang cukup lama, sedangkan keadaan mendesak tersebut memerlukan penanganan untuk diselesaikan.

Dari latar belakang diatas, maka penulis melakukan pengkajian yuridis terhadap PERPU No. 1 Tahun 2020 terkait dengan Kerugian Negara dengan menganalisis isu yang krusial yang sedang terjadi saat ini.

\subsection{Rumusan Masalah}

Berdasarkan latar belakang yang diuraikan di atas, maka penulis merumuskan masalah sebagai berikut: Pertama, Apakah latar belakang dari dikeluarkannya Peraturan Pemerintah Pengganti UU Nomor 1/2020? Kedua, Bagaimanakah batasan arti frasa "bukan merupakan kerugian negara" dan penerapan Itikad baik oleh pemerintah dalam Pasal 27 Peraturan Pemerintah Pengganti UU Nomor 1/2020?

\subsection{Tujuan Penelitian}

Berdasarkan pokok permasalahan tersebut maka tujuan penelitian ini adalah untuk dapat mengetahui makna dikeluarkannya Undang-Undang No. 2 Tahun 2020 tentang Penetapan Peraturan Pemerintah Pengganti UU Nomor 1 Tahun 2020 ("PERPU 1/2020") mengenai Kebijakan Keuangan Negara Dan Stabilitas Sistem Keuangan Untuk Penanganan Pandemi Corona Disease 2019 (“Covid-19”). Untuk dapat mengetahui makna Kerugian Negara dan Penerapan Itikad baik sesuai dengan Pasal 27.

\section{Metode Penelitian}

Metode penelitian yang digunakan dalam penulisan ini adalah metode yuridis normatif yaitu melalui studi pustaka yang menelaah data sekunder berupa Peraturan

${ }^{4}$ Maria Farida Indrati S, Imu PerUUan, Penerbit Kanisius, Jakarta, 2016, Hlm. 215-221 
Perundang-undangan yang berkaitan dengan PERPU, keuangan negara, kerugian negara dan asas-asas umum pemerintahan yang baik. Penelitian yang dilakukan dalam penelitian ini yaitu penelitian hukum normatif. Penelitian hukum normatif ialah penelitian hukum yang dilakukan dengan cara meneliti berbagai bahan pustaka atau bahan sekunder. ${ }^{5}$

Objek penelitian berupa norma atau kaidah hukum yang terdapat di dalam peraturan Perundang-undangan yang berkaitan dengan PERPU, keuangan negara, kerugian negara serta asas-asas umum pemerintahan yang baik. Data yang digunakan dalam penelitian ini adalah data sekunder dan data primer. Bahan hukum tersier merupakan bahan-bahan yang memberikan petunjuk maupun penjelasan terhadap bahan hukum primer dan bahan hukum sekunder antara lain kamus dan ensiklopedia. Data atau informasi yang diperoleh selanjutnya disajikan secara kualitatif dengan pendekatan deskiptif-analitis. ${ }^{6}$

\section{Hasil dan Pembahasan}

\subsection{Kewenangan Presiden}

Setelah adanya amandemen UUD 1945 terjadi pergeseran kewenangan. Reformasi politik yang terjadi pada tahun 1998 telah mendorong adanya perubahan dalam struktur ketatanegaraan Indonesia secara mendasar terutama yang menyangkut lembaga-lembaga Negara beserta kewenangannya. Salah satu diantaranya terkait dengan kekuasaan eksekutif yang berada dibawah tangan Presiden.

C.F. Strong di dalam bukunya Modern Political Constitution menjelaskan bahwa dalam Negara kesejahteraan, peranan eksekutif memegang peranan penting, bahkan juga mempunyai kewenangan yang cukup luas jika dirincikan meliputi: ${ }^{7}$

a. Kekuasaan Eksekutif (Executive Power)

b. Kekuasaan Administratif (Administrative Power)

c. Kekuasaan Militer (Legislative Power)

d. Kekuasaan Yudikatif (Judixial Power)

e. Kekuasaan Diplomatik (Diplomatic Power)

Begitu besarnya kekuasaan yang dimiliki Pemerintah atau Eksekutif maka diperlukan adanya pembatasan kekuasaan melalui mekanisme kontrol yang dilakukan oleh para wakil rakyat yang duduk di lembaga legislatif.

Tujuan utama dari amandemen UUD 1945 adalah untuk memperbaiki Sistem Ketatanegaraan yang ada di Indonesia. Di jelaskan dalam Pasal 22 ayat 1, 2, dan 3 terkait dengan kewenangan kepala negara (Presiden) dalam mengeluarkan PERPU tidak mengalami perubahan. Isi dari ketentuan Pasal 22 ayat 1, 2 dan 3 adalah sebagai berikut:

Pasal 22 ayat (1) berisikan: "Dalam hal ihwal kegentingan yang memaksa, Presiden berhak menetapkan peraturan pemerintah sebagai pengganti UU"

Pasal 22 ayat (2) berisikan: "Peraturan pemerintah itu harus mendapat persetujuan Dewan Perwakilan Rakyat dalam persidangan yang berikut"

Pasal 22 ayat (3) berisikan: "Jika tidak mendapat persetujuan, maka peraturan pemerintah itu harus dicabut"

${ }^{5}$ Soerjono Soekanto dan Sri Mamudji, Penelitian Hukum Normatif Suatu Tinjauan Singkat, CV Rajawali, Jakarta, 1985, Hlm. 13-15

${ }^{6}$ Ibid

7 Septi Nur Wijayanti dan Iwan Satriawan, Hukum Tata Negara, Fakultas Hukum Muhammadiyah Yogyakarta, Yogyakarta, 2009, hlm. 92 
Presiden dalam membuat Peraturan Pemerintah Pengganti UU (PERPU) selayaknya memperhatikan adanya sebuah kegentingan (hal ihwal) yang mendesak untuk segera menerbitkan peraturan tersebut. Kegentingan ini mempunyai parameter terkait dengan hak subjektif yang dimiliki oleh Presiden. Hak Subjektif yang dimiliki Presiden ini sangat menentukan ada atau tidaknya PERPU. Kegentingan ini biasanya terkait dengan adanya kondisi ekonomi, kondisi politik, dan kondisi keamanan. Bisa juga dapat terjadi karena Negara sedang mengalami kondisi darurat hukum.

Dalam putusan Mahkamah Konstitusi No. 138/PUU-VII/2009 disebutkan mengenai syarat kegentingan yang memaksa:

a. Adanya kebutuhan yang mendesak untuk menyelesaikan suatu masalah hukum secara cepat berdasarkan UU

b. UU yang dibutuhkan tersebut belum ada sehingga terjadi kekosongan hukum. Kalaupun UU nya sudah ada dianggap belum memadai untuk mengatasi keadaan.

c. Kekosongan hukum tersebut tidak dapat diatasi dengan cara membuat UU secara prosedur karena akan memakan waktu yang cukup lama. Padahal keadaan yang mendesak tersebut perlu adanya kepastian hukum.

\subsection{Latar belakang Peraturan Pemerintah Pengganti UU dan Kesesuaian Pembentukan PERPU No 1 Tahun 2020 dengan Asas-Asas Pembentukan Peraturan Perundang-undangan}

Tinjauan historis mengenai jenis peraturan Perundang-undangan, PERPU sebagai pengganti UU yang dibentuk dalam hal ihwal kegentingan yang Memaksa. PERPU merupakan jenis Perundang-undangan yang disebutkan dalam UUD 1945, yakni dalam Pasal 22. Pasal 22 UUD 1945 menyebutkan bahwa dalam hal ihwal kegentingan yang memaksa, Presiden berhak menetapkan PERPU. Pasal 1 angka 4 UU Nomor 12 Tahun 2011 memuat ketentuan umum yang memberikan definisi Peraturan Pemerintah Pengganti UU adalah peraturan Perundang-undangan yang ditetapkan oleh Presiden dalam hal ihwal kegentingan yang memaksa. Pasal 1 angka 3 Perpres 87 Tahun 2014 juga tidak memberikan tolak ukur pembatasan pengertian pada PERPU melainkan menyebutkan definisi yang sama sebagaimana tercantum dalam UU Nomor 12 Tahun 2011 dan UUD 1945.

PERPU sebenarnya merupakan suatu Peraturan Pemerintah yang bertindak sebagai suatu UU atau dengan perkataan lain PERPU adalah Peraturan Pemerintah yang diberi kewenangan sama dengan UU. Peraturan Pemerintah adalah peraturan Perundang-undangan yang dibentuk oleh Presiden untuk melaksanakan UU. UU yakni peraturan Perundang-undangan yang pembentukannya dilakukan oleh dua lembaga, yakni Dewan Perwakilan Rakyat dengan persetujuan Presiden dan merupakan peraturan yang mengatur lebih lanjut ketentuan-ketentuan dalam UUD 1945..$^{8}$ Maka PERPU merupakan Peraturan Pemerintah yang dibentuk dalam hal ihwal Kegentingan yang Memaksa untuk mengatur lebih lanjut ketentuan UUD 1945.

Sebagai salah satu jenis peraturan Perundang-undangan, PERPU juga wajib mengacu kepada Pancasila dan UUD 1945 sebagai sumber dari acuan hukum negara dan hukum dasar dalam Peraturan Perundang-undangan serta dapat menjadi sumber hukum peraturan Perundang-undangan yang lebih rendah. Berdasarkan rancangan awal bahwa PERPU merupakan suatu peraturan yang dari segi isinya seharusnya ditetapkan dalam bentuk UU, tetapi karena keadaan kegentingan memaksa ditetapkan

${ }^{8}$ Maria Farida Indrati, Ilmu PerUUan..., Op.Cit. Hlm.193 
dalam bentuk peraturan pemerintah maka dari itu kedudukan PERPU paling rasional dalam hierarki peraturan Perundang-undangan adalah sejajar dengan UU.

UUD 1945 menegaskan bahwa negara Indonesia adalah negara hukum, mengandung pengertian bahwa segala tatanan kehidupan berbangsa, bermasyarakat dan bernegara adalah didasarkan atas hukum, hal ini sesuai dengan Pasal 1 ayat 3 UUD 1945 oleh karena itu pelaksanaan Sistem Ketatanegaraan Indonesia harus berdasarkan pada Peraturan Perundang-undangan yang berlaku. Oleh karena itu pemerintah telah menetapkan UU Nomor 12 Tahun 2011 tentang Pembentukan Peraturan Perundang-undangan. Pada Pasal 5 UU Nomor 12 Tahun 2011 dijelaskan mengenai asas-asas Pembentukan Peraturan Perundang-undangan. Asas-asas yang dimaksud adalah

a. Asas Kejelasan Tujuan adalah bahwa setiap pembentukan Peraturan Perundang-undangan harus mempunyai tujuan yang jelas yang hendak dicapai.

b. Asas Kelembagaan atau Organ Pembentukan yang tepat adalah bahwa setiap jenis peraturan Perundang-undangan harus dibuat oleh lembaga atau pejabat pembentuk peraturan Perundang-undangan yang berwenang. Peraturan Perundang-undangan tersebut dapat dibatalkan atau batal demi hukum bila dibuat oleh lembaga atau pejabat yang tidak berwenang.

c. Asas Kesesuaian antara Jenis dan Materi Muatan adalah di dalam pembentukan Peraturan Perundang-undangan harus benar-benar memperhatikan materi muatan yang tepat dengan jenis peraturan Perundang-undangan.

d. Asas Dapat Dilaksanakan adalah bahwa setiap pembentukan peraturan Perundang-undangan harus memperhatikan efektifitas peraturan Perundangundangan tersebut didalam masyarakat baik secara filosofis, sosiologis dan yuridis.

e. Asas Kedayagunaan adalah bahwa setiap peraturan Perundang-undangan dibuat karena memang benar-benar dibutuhkan dan bermanfaat dalam mengatur kehidupan bermasyarakat, berbangsa dan bernegara.

f. Asas Kejelasan Rumusan adalah bahwa setiap peraturan Perundangundangan harus memenuhi persyaratan teknis penyusunan peraturan Perundang-undangan, sistematika, dan pilihan kata serta bahasa hukumnya jelas dan mudah dimengerti, sehingga tidak menimbulkan berbagai macam interpretasi dalam pelaksanaannya.

g. Asas Keterbukaan adalah bahwa dalam proses pembentukan peraturan Perundang-undangan mulai dari perencanaan, persiapan, penyusunan dan pembahasan bersifat transparan dan terbuka. Dengan demikian seluruh lapisan masyarakat mempunyai kesempatan yang seluas-luasnya untuk memberikan masukan dalam proses pembentukan peraturan Perundangundangan.

Hingga saat ini tak ada peraturan Perundang-undangan yang secara eksplisit mengatur kriteria kegentingan yang memaksa guna menjadi dasar baik bagi Presiden membentuk PERPU maupun bagi Dewan Perwakilan Rakyat (DPR) menerima/menolak pengajuan Rancangan UU (RUU) tentang penetapan PERPU, hal ini menimbulkan kerawanan Presiden dan DPR memanfaatkan PERPU sebagai alat kepentingan politik semata. Dominasi kepentingan politik terhadap kepentingan publik akan membawa negara pada kekuasaan absolut (tirani) yang condong kepada penindasan. Penindasan yang berlebihan terhadap hak dan kebebasan masyarakat 
berarti kekuasaan telah terbentuk dalam pola oligarki yang pada akhirnya berakibat perpecahan dan tindakan anarkisme masyarakat oleh akibat kesewenang-wenangan oleh penguasa. ${ }^{9}$

Jika dilihat dari asas-asas dalam Pembentukan Peraturan Perundang-undangan isi dalam PERPU No. 1 tahun 2020 tentang Kebijakan Keuangan Negara dan Stabilitas Sistem Keuangan Untuk Penanganan Pandemi Corona Disease 2019 atau Covid-19 telah mempunyai spirit yang sama dengan asas-asas Pembentukan Peraturan Perundang-undangan.

\subsection{Arti dan Batasan Frasa Bukan Merupakan Kerugian Negara}

Dilihat dari Pasal 1 angka 15 UU No. 15 Tahun 2006 tentang Badan Pemeriksa Keuangan dijelaskan bahwa yang dimaksud dengan Kerugian Negara adalah kerugian uang, surat berharga dan barang yang nyata dan pasti jumlahnya sebagai akibat perbuatan melawan hukum baik sengaja maupun lalai. Sedangkan yang dimaksud dengan Kerugian Negara jika dilihat dari Pasal 1 angka 22 UU No. 1 Tahun 2004 tentang Pembendaharaan Negara dijelaskan bahwa Kerugian Negara merupakan kekurangan uang, surat berharga dan barang yang nyata dan pasti jumlahnya sebagai akibat perbuatan melawan hukum baik sengaja maupun lalai. Dijelaskan lagi di dalam Pasal 32 ayat (1) UU No. 31 Tahun 1999 tentang Pemberantasan Tindak Pidana Korupsi yang dimaksud dengan Kerugian Negara adalah Kerugian yang sudah dapat dihitung jumlahnya berdasarkan hasil temuan instansi yang berwenang atau akuntan public yang ditunjuk.

Dalam penjelasan Pasal 59 ayat (1) mengenai Perbendaharaan Negara dapat dikatakan bahwa kerugian negara ini subyektif terjadi karena adanya pelanggaran hukum atau kelalaian pejabat negara atau pegawai negeri bukan bendahara dalam rangka pelaksanaan kewenangan administratif atau oleh bendahara dalam rangka pelaksanaan kewenangan mengelola keuangan. Penyelesaian kerugian negara perlu segera dilakukan untuk mengembalikan kekayaan negara yang hilang serta meningkatkan disiplin, tanggung jawab para pegawai negeri dan/atau pejabat negara lainnya yang menggunakan anggaran negara.

Dijelaskan dalam UU Badan Pemeriksa Keuangan (BPK) dan ketentuan dalam Keppres Nomor 103 Tahun 2001 tentang Kedudukan, Tugas, Fungsi, Kewenangan, Susunan dan Tata Kerja Lembaga Pemerintahan Non Departemen yang menetapkan ada atau tidaknya kerugian keuangan Negara adalah Badan Pengawas Keuangan (BPK) dan Badan Pengawas Keuangan dan Pembangunan (BPKP).

Bahwa berdasarkan beberapa hal yang tercantum pada peraturan Perundangundangan dapat diketahui unsur terpenting dari suatu kerugian Negara adalah adanya perbuatan melawan hukum dan nilai kerugian yang real. Oleh karena itu, pengaturan frasa "bukan merupakan kerugian Negara" dalam Pasal 27 ayat 1 PERPU No 1 Tahun 2020 agar tidak terjadi salah penafsiran atas Pasal tersebut maka perlu diatur lebih detail dalam penjelasan pasal demi pasal pada PERPU yang dimaksud.

\subsection{Keuangan Negara, Asas-asas Umum Pemerintahan yang baik (good governance) dan Bentuk Pertanggungjawaban Pemerintah dalam menjalankan pemerintahan \\ Dalam Pasal 23 UUD 1945 penjelasan mengenai Keuangan negara tidak diatur secara rinci dalam pasal tersebut. Pengertian keuangan Negara dibagi dalam dua}

${ }_{9}$ H.F. Abraham Amos, Sistem Ketatanegaraan Indonesia (dari Orla, Orba, sampai Reformasi), Raja Grafindo Persada, Jakarta 2005, Hlm. 433 
pengertian yaitu Pasca dan Pra Amandemen UUD 1945. Pasal 23 UUD 1945 pra amandemen dijelaskan yang dimaksud dengan Keuangan Negara hanya terbatas pada Anggaran Pendapatan dan Belanja Negara (APBN). Dijelaskan lebih lanjut oleh Jimly Asshidiqie Pengertian anggaran pendapatan dan belanja yang dimaksud dalam UUD $1945^{10}$ adalah hanya terkait dengan Anggaran Pendapatan dan Belanja Negara di tingkat Pusat, sehingga tidak tercakup Anggaran dan Belanja Daerah (APBD) yang sama sekali tidak berkaitan dengan tugas Badan Pemeriksa Keuangan (BPK)

Pasca adanya amandemen UUD makna dari Keuangan Negara tidak hanya termasuk dalam APBN tetapi termasuk juga di dalamnya ada APBD. Hal ini terkait dengan adanya perubahan struktur organisasi dan kewenangan dari BPK sendiri. Dalam Pasal 23 UUD 1945 mengenai hasil pemeriksaan keuangan yang dilakukan oleh BPK selain nantinya diserahkan kepada DPR sebagai pendapatan APBN juga diserahkan kepada DPD dan DPRD yang dimasukkan kedalam APBD sesuai dengan kewenangan dari setiap lembaga negara. ${ }^{11}$

Merujuk ketentuan Pasal 2 UU Nomor 17 Tahun 2003 tentang Keuangan negara dijelaskan sebagai berikut:

a. Hak negara di dalam memungut pajak, mengeluarkan dan mengedarkan uang dan melakukan pinjaman;

b. Kewajiban negara di dalam menyelenggarakan tugas layanan umum pemerintahan Negara dan membayar tagihan kepada pihak ketiga;

c. Penerimaan negara;

d. Pengeluaran negara;

e. Penerimaan Daerah;

f. Pengeluaran Daerah;

g. Kekayaan Negara ataupun kekayaan daerah yang dikelola sendiri ataupun oleh pihak lain berupa uang, surat berharga, piutang barang ataupun hak-hak lain yang dapat dinilai dengan uang termasuk juga kekayaan yang dipisahkan oleh Perusahaan Negara atau Perusahaan Daerah;

h. Kekayaan pihak lain yang dikuasai pemerintah dalam rangka penyelenggaraan tugas pemerintah dan kepentingan umum;

i. Kekayaan pihak lain yang diperoleh dengan menggunakan fasilitas yang diberikan oleh pemerintah.

Dipertegas dengan adanya Pasal 3 ayat (1) UU Nomor 15 Tahun 2004 mengenai Pemeriksaan dan Pengelolaan dan Tanggung Jawab Keuangan Negara menjelaskan terkait dengan pemeriksaan yang dilakukan oleh Badan Pemeriksa Keuangan mencakup seluruh komponen yang terdapat di dalam keuangan Negara sebagaimana yang dijelaskan dalam Pasal 2 UU tersebut. Objek di dalam Pemeriksaan Keuangan negara tidak hanya terbatas pada APBN dan APBD saja tetapi terkait dengan adanya BUMN dan BUMD yang mempunyai konsekuensi terkait dengan Keuangan Negara yang di dalamnya meliputi APBN, APBD, BUMN dan BUMD.

Akan tetapi jika dihubungkan dengan Pasal 23 UUD maka pengertian dari Keuangan Negara yang dilihat dari UU Nomor 17 Tahun 2003 dan UU Nomor 15 Tahun 2004 tidak sesuai karena Pasal 23 UUD menjelaskan bahwa Keuangan Negara

10 Jimly Asshidiqie, Sengketa Kewenangan Antar Lembaga Negara, Konstitusi Pers, Jakarta,2014, hlm 17

11 Arifin P. Soeia Atmadja, Keuangan Publik dalam Perspektif Hukum, Teori, Praktik dan Kritik, Badan Penerbit Fakultas Hukum Universitas Indonesia, Jakarta,2016, hlm 28 
hanya sebatas APBN dan APBD saja, tetapi menurut UU Nomor 17 Tahun 2003 dan UU Nomor 15 Tahun 2004 meliputi BUMN dan BUMD.

Untuk mewujudkan pengelolaan keuangan Negara yang baik maka diperlukan pengelolaan Pemerintahan yang bagus. Adapun prinsip-prinsip didalam melaksanakan pemerintahan yang baik (Good Governance) diantaranya adalah:

1. Asas Kepastian Hukum dalam Negara hukum yang mengutamakan landasan peraturan Perundang-undangan, kepatutan dan keadilan dalam setiap kebijakan penyelenggaraan Negara.

2. Asas Tertib Penyelenggaraan Negara yaitu asas yang menjadi landasan keteraturan, keserasian dan keseimbangan dalam pengendalian penyelenggaraan Negara.

3. Asas Kepentingan Umum yaitu asas yang mendahulukan kesejahteraan umum dengan cara yang aspiratif, akomodatif dan selektif.

4. Asas Keterbukaan yaitu asas yang membuka diri terhadap hak masyarakat untuk memperoleh informasi yang benar, jujur dan tidak diskriminatif tentang penyelenggaraan Negara dengan tetap memperhatikan perlindungan atas hak asasi pribadi, golongan dan rahasia Negara.

5. Asas Proporsionalitas adalah asas yang mengutamakan keseimbangan antara hak dan kewajiban penyelenggaraan Negara.

6. Asas Profesionalitas yaitu asas yang mengutamakan keahlian yang berdasarkan kode etik dan ketentuan dalam peraturan Perundang-undangan yang berlaku.

7. Asas Akuntabilitas yaitu asas yang menentukan bahwa setiap kegiatan dan hasil akhir dari kegiatan penyelenggaraan Negara harus dipertanggungjawabkan kepada masyarakat atau rakyat sebagai pemegang kedaulatan tertinggi Negara sesuai dengan ketentuan peraturan Perundangundangan yang berlaku. ${ }^{12}$

Asas-asas yang tercantum diatas tersebut pada awalnya ditujukan untuk diterapkan kepada para penyelenggara Negara secara keseluruhan. Selain itu Penyelenggaraan Negara wajib dalam melakukan segala tindakan atas dasar itikad baik (good faith) yang seharusnya menjadi ruh dalam memahami, melahirkan, dan melaksanakan pemerintahan.

Pertanggungjawaban berasal dari kata tanggung jawab dari kata tanggung jawab yang berarti keadaan wajib menanggung segala sesuatu (kalau ada sesuatu hal, boleh dituntut, dipersalahkan, diperkarakan, dan sebagainya). ${ }^{13}$ Di dalam kamus hukum terdapat dua istilah yang merujuk pada pertanggungjawaban yaitu liability dan responsibility. ${ }^{14}$

Dari responsibility ini muncul istilah responsible government yang menunjukkan bahwa istilah ini pada umumnya menunjukkan bahwa jenis- jenis pemerintahan dalam hal pertanggungjawaban terhadap ketentuan atau undang- undang public dibebankan pada departemen atau dewan eksekutif, yang harus mengundurkan diri apabila penolakan terhadap kinerja mereka dinyatakan melalui mosi tidak percaya, di dalam majelis legislatif, atau melalui pembatalan terhadap suatu undang- undang penting yang

dipatuhi.

Dalam pengertian dan penggunaan praktis, istilah liability menunjuk pada

\footnotetext{
12 Ridwan HR, Hukum Administrasi Negara, Rajawali Pers, Jakarta, 2014, hlm. 241-242

13 WJS. Poerwadarminta, Kamus Umum Bahasa Indonesia, Jakarta, 1976, hlm. 1014

14Ridwan HR, Hukum Administrasi Negara, Op. Cit, hlm. 241
} 
pertanggungjawaban hukum yaitu tanggung gugat akibat kesalahan yang dilakukan oleh subjek hukum, sedangkan responsibility menunjuk pada pertanggungjawaban politik. Dalam ensiklopedi administrasi, responsibility adalah keharusan seseorang untuk melaksanakan secara selayaknya apa yang telah diwajibkan kepadanya. Disebutkan juga bahwa pertanggungjawaban mengandung makna yakni meskipun seseorang memiliki keleluasaan dalam melaksanakan sesuatu tugas yang dibebankan kepadanya, namun tidak dapat membebaskan diri dari hasil atau dampak keleluasaan bertingkah laku dan dia dapat dituntut untuk melaksanakan secara layak apa yang diwajibkan kepadanya.

Dewan Perwakilan Rakyat untuk saat ini telah mengesahkan Peraturan Pemerintah Pengganti UU (PERPU) Nomor 1 Tahun 2020 mengenai "Kebijakan Keuangan Negara dan Stabilitas Keuangan untuk Penanganan Pandemi Covid-19 berubah menjadi UU pada tanggal 12 Mei 2020. Di dalam rapat paripurna yang dilaksanakan oleh DPR yang langsung diketuai oleh Ketua DPR Puan Maharani, hampir semua fraksi yang ada telah menyetujui disahkannya PERPU No 1 Tahun 2020.

Sri Mulyani Indrawati sebagai Menteri Keuangan Negara berharap PERPU yang disahkan menjadi UU ini dapat menjadi landasan hukum yang kuat bagi pemerintah di dalam menangani pandemi Corona, terutama dikhususkan di bidang kesehatan, ancaman social, ancaman perekonomian dan stabilitas system keuangan Negara. ${ }^{15}$ Aparatur penegak hukum wajib mentaati norma-norma hukum yang sudah ada dalam menegakkan hukum seperti norma kemanusiaan, norma keadilan, norma kepatutan (equity), dan norma kejujuran. Dalam penegakan hukum pidana saat ini, sering dijumpai paradoks antara penegakan hukum dengan aturan hukum yang ditegakkan, sehingga keadilan hukum yang diharapkan tersebut sangat jauh dari harapan. ${ }^{16}$

Sejak diberlakukannya PERPU No. 1 Tahun 2020, terdapat beberapa Pasal di dalam UU Keuangan Negara, UU Perbendaharaan Negara, UU KUP, UU BI, UU Perimbangan Keuangan antara Pemerintah Pusat dan Pemerintah Daerah, UU Kesehatan, UU Desa, UU Pemda, UU MD3, UU PPKSK, UU APBN Tahun Anggaran 2020 dinyatakan tidak berlaku sepanjang berkaitan dengan Kebijakan Keuangan Negara untuk menangani pandemic Covid-19 untuk mengatasi masalah perekonomian sosial atau Stabilitas Sistem Keuangan berdasarkan PERPU Nomor 1 Tahun 2020.

Frasa "bukan merupakan kerugian negara" dalam Pasal 27 ayat (1) dalam PERPU Nomor 1 Tahun 2020 ramai diamati oleh publik dikarenakan secara tidak langsung memberikan hak Imunitas bagi para pelaksana PERPU Nomor 1 Tahun 2020. Persoalan mengenai hak imunitas itu diantaranya adalah KSSK dan lembaga terkait yang tidak dapat dituntut secara perdata maupun pidana serta PERPU Nomor 1 Tahun 2020 tersebut bukan merupakan objek gugatan PTUN.

Menurut Simons, sebagai dasar pertanggungjawaban pidana adalah kesalahan yang terdapat pada jiwa pelaku dalam hubungannya (kesalahan itu) dengan kelakuan yang dapat dipidana dan berdasarkan kejiwaan itu pelaku dapat dicela karena

15 https://www.asumsi.co , Pro Kontra Pengesahan PERPU Corona Jadi UU, Diakses pada tanggal 30 Mei 2020 jam 19.00

${ }^{16}$ Iqbal, M. (2019). EFEKTIFITAS HUKUM DAN UPAYA MENANGKAL HOAX SEBAGAI KONSEKUESNI NEGATIF PERKEMBANGAN INTERKASI MANUSIA. Literasi Hukum, 3(2), 19. 
kelakuannya. Untuk adanya kesalahan pada pelaku harus dicapai dan ditentukan terlebih dahulu beberapa hal yang menyangkut pelaku, yaitu: ${ }^{17}$

a. Kemampuan bertanggungjawab;

b. Hubungan, kejiwaan antara pelaku dan akibat yang ditimbulkan (termasuk pula kelakuan yang tidak bertentangan dalam hukum dalam kehidupan sehari hari;

c. Dolus dan culpa, kesalahan merupakan unsur subjektif dari tindak pidana. Hal ini sebagai konsekuensi dari pendapatnya yang menghubungkan (menyatukan) straafbaarfeit dengan kesalahan.

Unsur tindak pidana dalam ilmu hukum pidana disebut juga elemen delik (unsur delik). Elemen delik itu adalah bagian dari delik. Dalam penuntutan sebuah delik, harus dibuktikan semua elemen delik yang dituduhkan kepada pembuat delik. Oleh karena itu jika salah satu unsur atau elemen delik tidak terpenuhi, maka pembuat delik tersebut tidak dapat dipersalahkan melakukan delik yang dituduhkan, sehingga pembuat delik harus dilepaskan dari segala tuntutan hukum (onslaag van rechts alle vervologing). Elemen delik umumnya terbagi dalam 2 (dua) bagian, yaitu: (1) unsur obyektif, atau yang biasa disebut actus reus, dan (2) unsur subyektif, atau yang biasa disebut mens rea. ${ }^{18}$

Unsur delik Obyektif adalah unsur-unsur yang ada hubungannya dengan keadaan-keadaan, yaitu dalam keadaan-keadaan mana tindakan-tindakan dari si pelaku itu harus dilakukan. Unsur obyektif dari tindak pidana meliputi: (a) sifat melawan hukum, (b) kualitas dari si pelaku, misalnya keadaan sebagai seorang Pegawai Negeri Sipil (PNS) sebagaimana diatur dalam Pasal 415 KUHP, dan (c) kausalitas, hubungan antara sesuatu tindakan sebagai penyebab dengan kenyataan sebagai akibat. Unsur delik obyektif adalah elemen delik yang berkaitan dengan perbuatan (act, daad) dari pelaku delik, yaitu: Wujud perbuatan aktif maupun pasif dan Perbuatan itu harus bersifat melawan hukum

Suatu delik dapat diwujudkan dengan kelakuan aktif ataupun kelakuan pasif, sesuai dengan uraian delik yang mensyaratkannya. Misalnya dalam delik pencurian biasa (Pasal 362 KUHP) wujud perbuatannya adalah mengambil barang milik orang lain sebagian atau seluruhnya. Contoh lain delik tidak memenuhi panggilan di sidang pengadilan sebagai saksi, ahli, juru bahasa (Pasal 224 KUHP). Jadi wujud perbuatan dimaksud adalah aktif atau pasif, meliputi jenis delik komisi, atau jenis delik omisi, atau delictum commissionis per ommissionem commissa, atau delik tidak mentaati larangan dilanjutkan dengan cara tidak berbuat.

Perbuatan yang diisyaratkan untuk memenuhi elemen delik obyektif adalah bahwa dalam melakukan perbuatan itu harus ada elemen melawan hukum (wedderectelijkheids, unlawfull act, onrechtma-tigedaad). Suatu perbuatan melawan hukum adalah perbuatan yang dilarang untuk dipatuhi, atau diperintahkan untuk tidak dilakukan seperti yang tercantum dalam aturan pidana. Hukum Pidana membedakan sifat melawan hukum menjadi 2 (dua) macam arti utama, yaitu: melawan hukum dalam arti formil dan melawan hokum dalam arti materiil.

Menurut Zainal Abidin menjelaskan bahwa dikatakan formil karena UU pidana melarang atau memerintahkan perbuatan itu disertai ancaman sanksi kepada barang siapa yang melanggar atau mengabaikannya. Arti perbuatan melawan hukum formil

17 Oemar Seno Adji, Etika Profesional Dan Hukum Pertanggungjawaban Pidana Dokter, Penerbit: Erlangga, Jakarta, 1991, Hlm. 34

18 Ibid 
adalah unsur-unsur yang bersifat konstitutif, yang ada dalam setiap rumusan delik dalam aturan pidana tertulis, walaupun dalam kenyataanya tidak dituliskan dengan tugas bersifat melawan hukum. Dengan demikian dalam hal tidak dicantumkan berarti unsur melawan hukum diterima sebagai unsur kenmerk (diterima secara diamdiam, implicit). Melawan hukum formil lebih mementingkan kepastian hukum (rechtszekerheids) yang bersumber dari asas legalitas (principle of legality, legaliteit benginsel). ${ }^{19}$

Disebut materiil oleh karena sekalipun suatu perbuatan telah sesuai dengan uraian di dalam UU, masih harus diteliti tentang penilaian masyarakat apakah perbuatan itu memang tercela dan patut dipidana pembuatnya atau tidak tercela, ataupun dipandang sifatnya terlampau kurang celaannya sehingga pembuatnya tak perlu dijatuhi sanksi pidana, tetapi cukup dikenakan sanksi dalam kaidah hukum lain, atau kaidah sosial lain. Arti perbuatan melawan hukum materiil adalah unsur yang berkaitan dengan asas culpabilitas (penentuan kesalahan pembuat delik), atau nilai keadilan hukum yang ada dalam masyarakat, dan tingkat kepatutan dan kewajaran.

Suatu perbuatan dikualifikasi sebagai telah terjadi delik, bila dalam perbuatan itu tidak terkandung Dasar Pembenar, sebagai bagian dari Elemen Delik Obyektif (actus reus). Dimaksudkan dengan Dasar Pembenar adalah dasar yang menghilangkan sifat melawan hukum dari perbuatan yang sudah dilakukan pembuat delik. Artinya jika perbuatan itu mengandung dasar pembenar berarti salah satu unsur delik (elemen delik) obyektif tidak terpenuhi, yang mengakibatkan pelaku (pembuat) delik tidak dapat dikenakan pidana. Dalam KUHP terdapat beberapa jenis Dasar Pembenar, yaitu: (1) Daya Paksa Relatif (vis compulsiva), (2) Pembelaan Terpaksa, (3) Melaksanakan Perintah UU, dan (4) Melaksanakan Perintah Jabatan Yang Berwenang.

Mengenai konsep hukum pidana dibeberapa negara, pengaturan mengenai hak imunitas hukum sebenarnya bukan hal yang baru. Kitab UU Hukum Pidana (KUHP) telah mengatur soal hak imunitas sebagaimana tertuang dalam Pasal 50 KUHP. Pasal ini menetapkan tidak (dapat) dipidananya seseorang yang melakukan perbuatan yang merupakan suatu tindak pidana untuk melaksanakan ketentuan UU.

Merujuk pada Pasal 50 KUHP seorang pejabat memiliki dasar pembenar untuk melakukan suatu perbuatan yang sesungguhnya dapat dipidanakan jika dilakukan bukan karena adanya perintah peraturan perundangan. Pasal lainnya terkait dengan masalah hak imunitas ialah Pasal $51 \mathrm{KUHP}$, yang menetapkan seseorang tidak dapat dipidana karena melakukan perbuatan berdasarkan perintah jabatan yang sah atau diyakini sah dari pejabat yang berwenang memberikan perintah.

Secara sederhana, konsep mengenai hak imunitas fungsional dapat dipahami sebagai pemberian kekebalan hukum dari tuntutan hukum kepada seorang pejabat yang karena kedudukan, tugas, dan fungsinya bertindak untuk dan atas nama suatu negara melakukan perbuatan tertentu, padahal perbuatan tersebut ternyata dapat dipidanakan menurut hukum dari negara yang menjadi tempat dilakukannya perbuatan tersebut.

Hak Imunitas fungsional ini sesungguhnya diatribusikan kepada negara yang diwakili pejabat tersebut, sehingga meskipun pejabat yang melakukan perbuatan itu telah berhenti menjabat maka kekebalan hukum yang terkait dengan perbuatannya tetap melekat pada diri pejabat yang bersangkutan.

Sedangkan hak imunitas personal dipahami sebagai kekebalan terhadap tuntutan hukum yang diberikan kepada pejabat suatu negara atas perbuatan yang bisa

${ }^{19}$ H.A. Zainal Abidin Farid, Hukum Pidana I, Sinar Grafiika, Jakarta, 2007, Hlm. 242. 
dipidanakan tanpa melihat lagi apakah perbuatan itu dilakukan atas nama negara atau merupakan perbuatan pribadi. Dari sisi pembedaan itu, imunitas yang hendak diberikan oleh Pasal 27 ayat 1 Perppu 1/2020 tampaknya bisa dikategorikan baik sebagai imunitas fungsional maupun personal.

Namun banyak ahli hukum yang menganggap tidak perlu sebuah UU membuat pasal pemberian hak imunitas lagi sehubungan adanya Pasal 50 KUHP. Bahkan adanya pasal itu dianggap menunjukkan bahwa yang menyusun UUnya tidak paham terhadap konsep dasar hukum pidana. Sesungguhnya Imunitas hukum vide Pasal 27 ayat (1) PERPU No. 1 Tahun 2020 banyak terdapat dalam beberapa UU lain.

Kita dapat melihat misalnya pada Pasal 45 UU Nomor 23 Tahun 1999 tentang Bank Indonesia ("UU BI") mengenai jabatan dewan gubernur dan pejabat Bank Indonesia. Selanjutnya untuk Pasal 10 UU Nomor 37 Tahun 2008 tentang Ombudsman Republik Indonesia (“UU ORI”) untuk para Komisioner Ombudsman. Bahkan untuk anggota DPR, hak imunitas disebut dalam Pasal 20A ayat (3) UUD NRI Th. 1945 dan kemudian diatur lebih lanjut dalam UU Nomor 17 Tahun 2014 tentang MPR, DPR, DPD Dan DPRD (“UU MD3").

Terdapat dua syarat yang perlu diperhatikan, seperti halnya dalam beberapa kasus pidana berkaitan dengan hak imunitas maka setidaknya perlu adanya prinsip iktikad baik dalam pengambilan kebijakan dan/atau pelaksanaannya menjadi bagian dari aspek kasus tersebut sedang diselidiki oleh aparat penegak hukum. Biasanya penyelidikan tersebut dilakukan dalam kerangka pembuktian unsur pidana "dengan sengaja", "dengan bahwa", "mengetahui bahwa" yang ada dalam pasal pidana yang akan dipersangkakan kepada orang tersebut.

Demikian halnnya, aspek pelanggaran terhadap peraturan perundangan juga menjadi objek penyelidikan. Jika penegak hukum meyakini bahwa kedua aspek ini diyakini telah diabaikan, maka proses hukum tetap dijalankan meski ada pasal imunitas dalam UU terkait. Contoh nyata soal dilanggarnya prinsip itikad baik dan peraturan perundangan dapat kita lihat dari kasus korupsi yang timbul dalam pelaksanaan kebijakan dana talangan (bail out) Bank Century. Walaupun terdapat Pasal 45 UU BI yang memberikan hak imunitas hukum kepada pejabat BI, namun proses hukum tetap dilakukan.

\section{Penutup}

\subsection{Kesimpulan}

Pertama, Peraturan Pemerintah Pengganti UU (PERPU) adalah Peraturan Perundang-undangan yang ditetapkan oleh Presiden dalam hal ihwal kegentingan yang memaksa. Dalam hierarki Peraturan Perundang-undangan di Republik Indonesia kedudukan PERPU ini disejajarkan dengan UU. Ketika PERPU ini disampaikan ke DPR dan DPR menyetujui terhadap PERPU yang dibuat oleh Presiden maka PERPU tersebut berubah menjadi UU. Tolak ukur dari "Kegentingan yang Memaksa" dalam pembentukan PERPU semestinya diatur dengan jelas dalam suatu peraturan Perundang-undangan, agar tercipta suatu mekanisme kontrol yang lebih baik dalam pembentukan PERPU. Namun hingga sampai saat ini, baik di UU Dasar Negara Republik Indonesia Tahun 1945, UU Nomor 12 Tahun 2011 tentang Pembentukan Peraturan Perundang-undangan maupun Peraturan Presiden Nomor 87 Tahun 2014 tentang Peraturan Pelaksanaan UU Nomor 12 Tahun 2011 tentang Pembentukan Peraturan Perundang-undangan, Peraturan Presiden Nomor 87 Tahun 2014 yang menyebutkan tentang kewenangan Presiden menetapkan PERPU yang didasarkan pada hal ihwal kegentingan yang memaksa, tidak memuat tolak ukur yang jelas 
mengenai apa yang digolongkan sebagai Kegentingan yang Memaksa. Bahwa terhadap Pemerintah Pengganti UU Nomor 1/2020 (PERPU No 1/2020) Tentang Kebijakan Keuangan Negara Dan Stabilitas Sistem Keuangan Untuk Penanganan Pandemi Corona Disease 2019 Atau Covid-19 sudah sesuai mekanisme yang ada berdasarkan ketentuan Perundang-undangan dan telah di sahkan oleh Dewan perwakilan Rakyat (DPR) menjadi UU Nomor 2 Tahun 2020 Tentang Penetapan Peraturan Pemerintah Pengganti UU Nomor 1 Tahun 2020 Tentang Kebijakan Keuangan Negara Dan Stabilitas Sistem Keuangan Untuk Penanganan Pandemi Corona Disease 2019 Atau Covid-19.

Kedua, Terkait dengan hal-hal yang terdapat dalam Pasal 27 PERPU No 1 Tahun 2020 juga dinilai berpotensi memunculkan korupsi dengan adanya Pasal 27 ayat 1 terutama frasa "bukan merupakan kerugian Negara". Unsur terpenting dari suatu kerugian Negara adalah adanya perbuatan melawan hukum dan nilai kerugian yang riill. Oleh karena itu, pengaturan frasa "bukan merupakan kerugian Negara" dalam Pasal 27 ayat 1 PERPU No 1 Tahun 2020 agar tidak terjadi salah penafsiran atas Pasal tersebut maka perlu diatur lebih detail dalam penjelasan pasal demi pasal pada PERPU yang dimaksud. Adanya penafsiran imunitas berkonotasi "kebal hukum" dalam Perppu 1/2020 tidak serta-merta harus dimaknai adanya pelanggaran prinsip persamaan di hadapan hukum bagi seluruh warga negara Indonesia vide Pasal 27 ayat 1 UUD 45.

\subsection{Saran}

Pertama, Penyusunan peraturan Perundang-undangan mempunyai urutan tahapan perencanaan, penyusunan, pengesahan/penetapan dan pengundangan. PERPU yang sejatinya disusun sewaktu Kegentingan yang memaksa mendefinitifkan tahapan perencanaan tidak dilakukan, karena keadaannya bersifat tidak terduga serta tanpa adanya suatu rencana. Kegentingan yang memaksa pada umumnya hanya ditafsirkan pada persoalan urgent semata bagi Presiden untuk menyelesaikan suatu permasalahan atau kebutuhan hukum. Berdasarkan hal-hal yang telah diuraikan diatas, maka tolak ukur terhadap Kegentingan yang Memaksa minimal harus memenuhi unsur kemendesakan untuk mengatasi suatu permasalahan yang mengancam nyawa dan/atau harta, bangsa dan negara yang bersifat masif atas suatu permasalahan hukum yang mengancam tatanan hukum yang telah berlaku. Proses penyusunan hingga terbentuknya PERPU dilihat dari unsur kegentingan memaksa harus dapat mengawasi dan membatasi penggunaan hak subjektif Presiden, sehingga perlu dirumuskan UU yang tidak hanya menjelaskan mengenai kriteria minimum yang dibutuhkan untuk proses pembentukan PERPU, namun juga harus mengikat Dewan Perwakilan Rakyat dalam pertimbangannya memberikan persetujuan atau tidak terhadap PERPU yang diajukan oleh Presiden kepada legislatif.

Kedua, terkait Permasalahan "kebal hukum" itu tidak otomatis memberikan hak imunitas kepada pejabat yang bersangkutan terhadap semua keadaan untuk tidak dapat dilakukannya proses hukum berupa penyelidikan, penyidikan dan penuntutan pidana maupun penuntutan secara perdata. Aparatur penegak hukum yang berwenang tidak bisa semena-mena menggunakan pasal "kebal hukum" ini untuk melakukan imunitas dengan tidak melakukan proses hukum dalam hal terdapat dugaan tindak pidana korupsi, perbankan atau tindak pidana umum apapun lainnya terkait pelaksanaan materi muatan PERPU 1/2020. Ruang proses hukum tetap harus terbuka ketika prinsip iktikad baik dan peraturan Perundang-undangan bagi setiap 
pejabat yang melanggar serta melakukan perbuatan melawan hukum dalam melaksanakan tugasnya.

\section{Daftar Pustaka}

Arifin P. Soeia Atmadja, Keuangan Publik dalam Perspektif Hukum, Teori, Praktik dan Kritik, Jakarta, Badan Penerbit Fakultas Hukum Universitas Indonesia, 2016.

H.A. Zainal Abidin Farid, Hukum Pidana I, Jakarta: Sinar Grafiika, 2007.

H.F. Abraham Amos, Sistem Ketatanegaraan Indonesia (dari Orla, Orba, sampai Reformasi), Jakarta: Raja Grafindo Persada, 2005.

Jimly Asshidiqie, Sengketa Kewenangan Antar Lembaga Negara, Jakarta, Konstitusi Pers: 2014.

Maria Farida Indrati S, Imu Perundang-undangan, Jakarta, Penerbit Kanisius: 2016.

Meriam Budiardjo, Demokrasi di Indonesia: Demokrasi Parlementer dan Demokrasi Pancasila, Cet. 2, Jakarta, Gramedia: 1996.

Muhammad Djafar Saidi, Hukum Keuangan Negara, PT Rajagrafindo Persada, Jakarta: 2008.

Oemar Seno Adji, Etika Profesional Dan Hukum Pertanggungjawaban Pidana Dokter, Jakarta, Erlangga: 1991.

Ridwan HR, Hukum Administrasi Negara, Jakarta: Rajawali Pers, 2014.

Soerjono Soekanto dan Sri Mamudji, Penelitian Hukum Normatif Suatu Tinjauan Singkat, Jakarta: CV Rajawali, 1985.

Septi Nur Wijayanti dan Iwan Satriawan, Hukum Tata Negara, Yogyakarta: Fakultas Hukum Muhammadiyah Yogyakarta, 2009.

WJS. Poerwadarminta, Kamus Umum Bahasa Indonesia, Jakarta, 1976. 